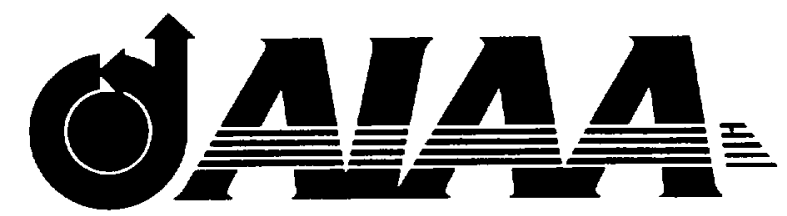

NASA-CR-202585

\title{
AIAA-95-1056
}

\section{Study of Resource Recovery and Epidemiology in an Anaerobic Digester}

K. Li, S. Cao, M. Hunt, and X. Fu

Lamar University

Beaumont, TX

\section{Life Sciences and Space Medicine Conference April 3-5, 1995 / Houston, TX}

For permission to copy or republish, contact the American Institute of Aeronautics and Astronautics 370 L'Enfant Promenade, S.W., Washington, D.C. 20024 



\title{
'STUDY OF RESOURCE RECOVERY AND EPIDEMIOLOGY IN AN ANAEROBIC DIGESTER
}

\author{
K. Y. Li and Song Cao \\ Chemical Engineering Department \\ M. D. Hunt and Xuping Fu \\ Biology Department \\ Lamar University, Beaumont, TX 77710
}

\begin{abstract}
Three 4-liter packed-bed anaerobic digesters were fabricated and operated at $35^{\circ} \mathrm{C}$, $\mathrm{pH}$ around 7 , and hydraulic retention time (HRT) of 20,10 and 5 days to study the resource recovery and epidemiology in a controlled ecological life support system (CELSS). A simulated wastewater, consisted of shower water, clothwash water, dishwash water, handwash water, and urine flush water was used as the feeding solution. Under steady-state operation, COD, TOC, $\mathrm{pH}$, nitrogen, phosphorus, and potassium were monitored in the digester input and output solutions. The volume and the $\mathrm{CH}_{4} / \mathrm{CO}_{2}$ ratio in the biogas produced from the anaerobic digesters were measured. The results indicate about $90 \%$ of TOC is converted while only $5-8 \%$ of N-P-K are consumed in the digester. A multi-drug resistant strain of Salmonella choleraesuis was used as the indicator bacterium in the epidemiology study. The levels of Salmonella choleraesuis in the influent and effluent were determined and decimal decay rate constants, $k_{d}$, were estimated. The $k_{d}$ values were greater at higher initial doses than lower doses for the same HRT, and greater for batch digestion (7.89/d) than for continuous digestion $(4.28,3.82$ and $3.82 / \mathrm{d}$ for 20 , 10 , and $5 \mathrm{~d}$ HRT, respectively).
\end{abstract}

\section{Introduction}

Currently, spacecraft life support systems are simple and sufficiently reliable for human space-flight missions of relatively short duration with small crew sizes and limited power availability. However, life support technologies for the coming era of exploration must address longer-duration missions in which humans require substantial amounts of consumable materials to sustain life for long periods of time. If these consumable materials must be provided by re-supply flights from Earth, a substantial logistics infrastructure is

Copyright $O$ American Institute of Aeronaustics and Astronautics, Inc., 1995. All rights reserved. required. Consequently, supplying all these consumables from Earth is an extremely expensive proposition. As a result, one of the most important challenges associated with longer-duration manned space flights is the development of a Controlled Ecological Life Support System (CELSS). This includes the technologies of air revitalization, water recovery, waste processing, food production, and food processing, all of which are logistically and economically essential for the resource recovery in a CELSS. $1,4,7,8$

The major elements in a CELSS are carbon (C), hydrogen $(\mathrm{H})$, oxygen $(\mathrm{O})$, and nitrogen $(\mathrm{N})$; and the minor elements are phosphorus $(\mathrm{P})$, potasium $(\mathrm{K})$, sodium (Na), Calcium (Ca) etc. A simplified element flow-diagram of a CELSS is presented in Figure 1. This figure illustrates the fundamental flow of major elements through the system.

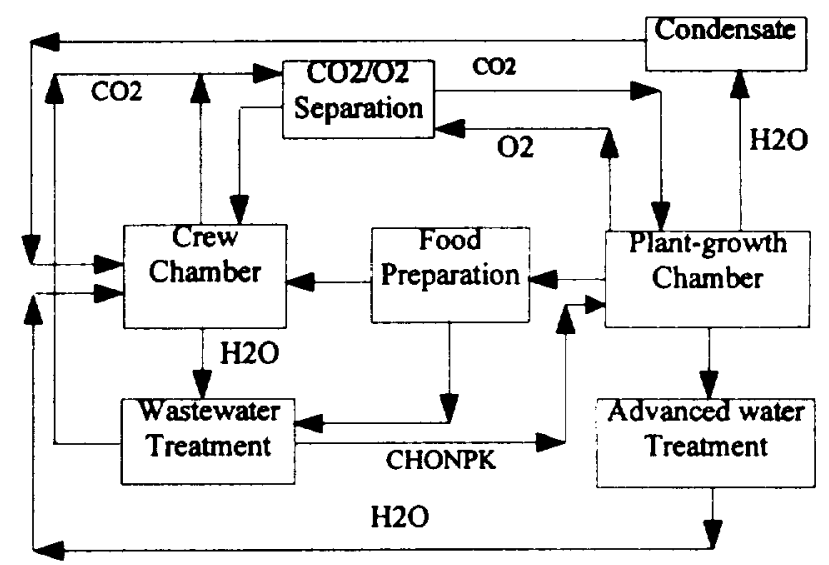

Fig 1. A simplified element flow-diagram of a CELSS.

In this example, crop plants are used to produce food for the crew. In addition to serving as the food production subsystem, the plants take up $\mathrm{CO}_{2}$ produced by the crew, produce oxygen for the crew to breathe and 
for oxidation of waste materials, and produce water vapor that can be condensed and collected to supply the crew's drinking and hygiene water. In the food processing subsystem, the foodstuffs produced by the crop plants are converted to a form palatable to the crew. Urine and feces, miscellaneous solid wastes, and waste biomass from the food processing subsystem are treated first in the wastewater treatment subsystem and then supplied to the plant growth chamber. The water out from the plant growth chamber is then further treated by an advanced water treatment subsystem. Any pure water produced from the advanced water treatment subsystem or from the condensate is supplied to the crew chamber.

Technologies for wastewater treatment include physical, chemical and biological methods. In general it is believed that a hybrid treatment system performs better than a single system. A combination process of anaerobic digester with a plant growth chamber, and an advanced water treatment unit was proposed for resource recovery and epidemiology study in a CELLS. ${ }^{3} \mathrm{~A}$ conceptual flow diagram of this process is shown in Figure 2. Advantages for anaerobic bio-process are 1) methane gas is produced 2) less biomass is generated than aerobic process, and 3) the effluent is rich in inorganic nutrient for plant growth. Combining plantgrowth with anaerobic bacterial systems provides distinct advantages. For an example, the efficiency of removal of ammonium and nitrate nitrogen can be increased during plant growth when compared to bacterial systems without plant growth.

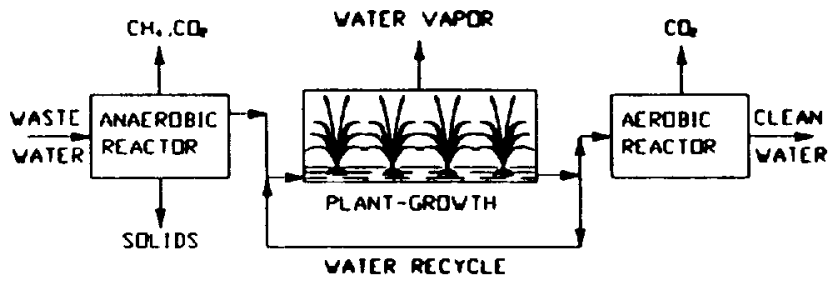

Fig. 2. Flow-diagram of an anaerobic/plant-growth/ aerobic process

Wastewater containing human feces can present biological hazards when the intestinal flora consists of pathogenic species of bacteria belonging to genera such as Salmonella, Shigella and Vibrio. They can cause illness if given the proper environmental conditions that enhance their growth and their transmission. Thus, the risk of transmission of infectious diseases must be a consideration in the treatment of wastewater. In this study, three 4-liter packed-bed anaerobic reactors were build and used to test the resource recovery and epidemiology. Information obtained from this study will be very helpful for the development of a hybrid wastewater treatment system in combining an anaerobic process with a plant growth chamber.

\section{Experiment}

The experimental setup of each digester is shown in Figure 3. The digester is a 4 liter glass reaction kettle (ACE Glass 6505) packed with 5/8" size of polypropylene pall rings. Two perforated plexiglass with $1 / 8^{\prime \prime}$ thickness plates were used to hold the packing material inside the reactor. Characteristics of the packing materials are listed in Table 1. A magnetic drive pump was used to circulate the solution and to keep the liquid phase uniform after the injection of the feed solution. The reactor was placed in $35^{\circ} \mathrm{C}$ incubator to obtain mesophilic condition. Biogas was collected by a gas collection system which also can be seen from Figure 3.

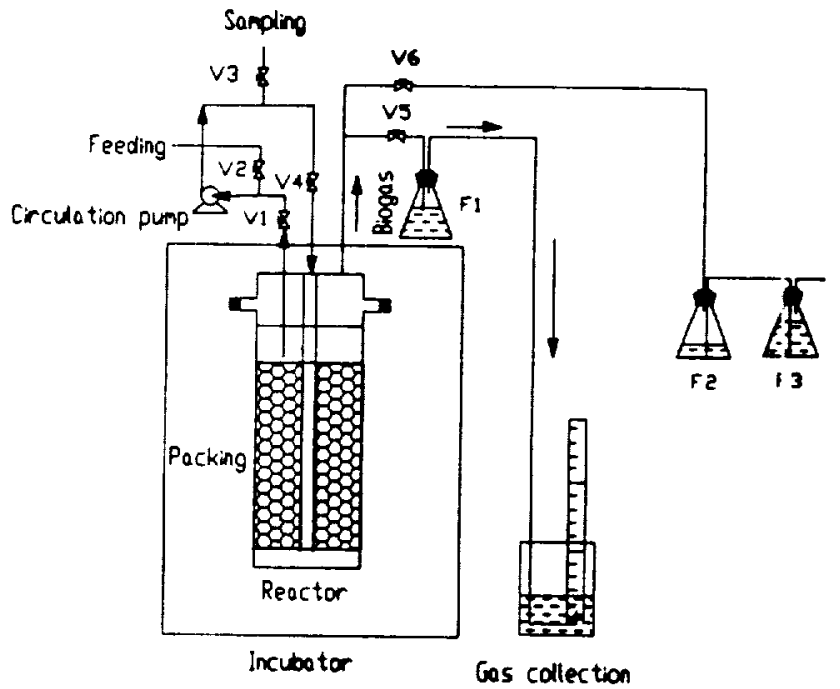

Fig. 3. Experimental setup of an anaerobic digester.

The ratio of $\mathrm{CH}_{4} / \mathrm{CO}_{2}$ in the biogas was measured by gas chromatography (GOW-MAC 350) with thermal conductivity detector using a 6 feet Haysep-Q packed column. The total organic carbon (TOC) in the aquecrus solution was determined by a TOC analyzer (TOC- 5000 , 
Shimadza Scientific Instrument, Inc.). The chemical oxygen demand (COD), total nitrogen $(\mathrm{N})$, total phosphorus $(\mathrm{P})$, and potassium $(\mathrm{K})$ were detected by using a HACH spectrophotometer (Model 2000).

Table 1. Characteristics of Pall rings.

\begin{tabular}{ll}
\hline material & polypropylene \\
size & $16 \times 16 \mathrm{~mm}$ \\
surface area & $0.00342 \mathrm{~m}^{2} / \mathrm{g}$ \\
specific area & $3.412 \mathrm{~cm}^{-1}$ \\
porosity & 0.877 \\
\hline
\end{tabular}

The inorganic nutrients used in this study are listed in Table 2. This formula supply the necessary major and micro nutrients, reducing agents to remove the oxygen in the solution, and buffer solution.

Table 2. List of inorganic nutrients

\begin{tabular}{|l|c|}
\hline chemicals & $\begin{array}{c}\text { concentration } \\
\text { (mg/l) }\end{array}$ \\
\hline $\mathrm{CaCl}_{2} \cdot \mathrm{H}_{2} \mathrm{O}$ & 6.25 \\
\hline $\mathrm{NaPO}_{3}$ & 0.25 \\
\hline$\left(\mathrm{NH}_{4}\right)_{2} \mathrm{HPO}_{4}$ & 96.50 \\
\hline $\mathrm{L}-c y s t e i n$ & 2.50 \\
\hline $\mathrm{CoCl}_{2} \cdot 6 \mathrm{H}_{2} \mathrm{O}$ & 10.00 \\
\hline $\mathrm{FeCl}_{2} \cdot 4 \mathrm{H}_{2} \mathrm{O}$ & 20.00 \\
\hline $\mathrm{Na}_{2} \mathrm{~S}_{2} 9 \mathrm{H}_{2} \mathrm{O}$ & 75.00 \\
\hline $\mathrm{MgCl} \cdot 6 \mathrm{H}_{2} \mathrm{O}$ & 266.75 \\
\hline $\mathrm{NH} \mathrm{Cl}_{4}$ & 369.00 \\
\hline $\mathrm{KCl}$ & 100.00 \\
\hline $\mathrm{KI}$ & .63 \\
\hline $\mathrm{NaHCO}$ & pH adjustment \\
\hline
\end{tabular}

All the chemicals used in this study were ordered from Fisher Scientific and Aldrich with ACS grade chemical pure. The simulated wastewater consists of clothwash water, dishwash water, handwash water, shower water, fresh urine, and urine flush. The formula of the simulated wastewater was specified by NASAJSC and is shown in Table 3. Deionized water was used to prepare the simulated wastewater which was prepared freshly prior to each feeding. The soap used in this experiment was provided by NASA-JSC.

Table 3. Formulation of NASA simulated wastewater.

\begin{tabular}{|l|c|}
\hline Item & U/person/day \\
\hline $\begin{array}{l}\text { shower water (4uses } \\
\text { /d, 12 g soap/use) }\end{array}$ & 5.32 \\
\hline $\begin{array}{l}\text { hand wash (16 } \\
\text { uses/d, 2g soap/use) }\end{array}$ & 4.07 \\
\hline $\begin{array}{l}\text { clothes wash (30 g } \\
\text { soap) }\end{array}$ & 12.44 \\
\hline urine (16 uses/d) & 1.51 \\
\hline urine flush & 0.49 \\
\hline dish wash & 9.07 \\
\hline total & 32.90 \\
\hline
\end{tabular}

A multi-drug resistant strain (RS) of Samonella choleraesuis, subspecies: choleraesuis, serotype: typhi, antigenic formula: 9, 12, Vi:d was obtained from American Type Culture Collection (ATCC No. 19214) and was used as the indicator bacterium in this study. This strain is resistant to chloramphenicol, tetracycline, streptomycin, and sulfanilamide. It is not known to be part of the indigenous flora of animals nor is it known to occur in nature. A wild strain of Samonella choleraesuis, non-resistant to the above antibiotics (NRS), was utilized in the experiment as the control. It was routinely streaked on the antibiotic-containing agar plates to check the inhibitory action of the medium.

Nutrient agar and nutrient broth (Fisher, Pittsburgh) were used as growth and storage media for the RS and NRS bacteria. MacConkey agar CS (Difco, Detroit) was used as a bacterial quantification medium. It was supplemented, after sterilization, with chloramphenicol, streptomycin, tetracycline, and 
sulfanilamide (Sigma, St. Louis) at concentrations that inhibited growth of NRS but not the RS bacteria. This medium was therefore referred to as MacConkeyantibiotic agar.

The experiment started by immobilization and acclimation of the bacteria in the digester. Seeding solution (3.5 liter) was obtained from a local municipal wastewater treatment plant and was added to each anaerobic digester. Initially, local municipal wastewater was used as the feed solution. However, after biogas procuction was observed, the feed solution was changed gradually to NASA simulated wastewater. Experimentation was begun when the digesters achieved a steadystate of gas production and $\mathrm{pH}$.

A volume of $350 \mathrm{ml}$ of the digester solution was withdrawn from the anaerobic digesters after steady-state had been achieved. Afterward, $3.5 \mathrm{ml}$ of Salmonella bacterial suspension was injected into the digesters through the rubber tube of the input valve. Following injection, the bacterial suspension was flushed with $346.5 \mathrm{ml}$ of simulated wastewater. This withdrawn-andfed was done at an interval determined by the hydraulic retention time (HRT). The Salmonella population in the digester was measured from the $350 \mathrm{ml}$ withdrawn solution. For the decay study of Salmonella bacteris in a batch digester, five $\mathrm{ml}$ of solution was withdrawn from the batch digester after 3,6,12, and 24 hours for $\mathrm{pH}$ measurements and colony counts. The excess solution was re-injected into the digester after each measurement.

Viable counts of the indicator bacteria were determined by preparing 10-fold serial dilutions of the solution in $0.1 \%$ peptone water. One-tenth $\mathrm{ml}$ volumes of the dilutions were spread with sterile glass L-rods over the MacConkey-antibiotic agar plates. Colony counts (CFU/ml) were determined after 24 hours of incubation at $35^{\circ} \mathrm{C}^{2}$ The biofilms on the pall rings were examined at the conclusion of the study for the presence of attached indicator bacteria. One pall ring was selected and was mixed with peptone water with the use of a votex mixer. The mixed suspension was then streaked on MacConkey-antibiotic plate, and the suspect colonies were identified by the Crystal Identification System after 24 hours incubation. No indicator bacteria were isolated on the MacConkeyantibiotic plate from seeding or simulated wastewater. However, Pseudomonas aeruginosa from the seeding solution was detected.

\section{Result and Discussion}

\section{Resource Recovery}

The performance of the anaerobic digester may be seen from Table 4. At the steady state operating condition, the TOC removal percent $(87.13 \pm 0.03$, $89.01 \pm 0.03$, and $88.78 \pm 0.02$ for 20,10 , and $5 \mathrm{~d}$ HRT, respectively) seems independent from the HRT. This result is in consistent with the biogas produced from the digester. However, the COD removal percent $(81.92 \pm 5.25,74.61 \pm 8.67$, and $68.18 \pm 9.90$ for 20 , 10 , and $5 \mathrm{~d} \mathrm{HRT}$, respectively) decreases as the HRT decreases as shown in the table. The standard deviation of COD values is quite high compared with that of TOC values. With this large standard deviation of COD, it may not be able to conclude that the decrease of $C O D$ with HRT is significant.

Table 4. Performance of the anaerobic digester.

\begin{tabular}{|l|l|l|l|}
\hline HRT, day & \multicolumn{1}{|c|}{20} & 10 & 5 \\
\hline $\begin{array}{l}\text { TOC inf } \\
\mathrm{mg} / \ell\end{array}$ & 601.1 & 600.4 & 465.7 \\
\hline $\begin{array}{l}\mathrm{TOC} \text {,eff } \\
\mathrm{mg} / \ell\end{array}$ & 77.3 & 65.98 & 52.25 \\
\hline $\begin{array}{l}\text { TOC load } \\
\mathrm{g} / \mathrm{m}^{3} / \mathrm{d}\end{array}$ & 29 & 58 & 106 \\
\hline $\begin{array}{l}\mathrm{COD}, \text { inf } \\
\mathrm{mg} / \ell\end{array}$ & 2336 & 2393 & 2401 \\
\hline $\begin{array}{l}\mathrm{COD}, \text { eff } \\
\mathrm{mg} / \ell\end{array}$ & 422.3 & 607.8 & 764.0 \\
\hline $\begin{array}{l}\mathrm{COD} \text { load } \\
\mathrm{g} / \mathrm{m}^{3} / \mathrm{d}\end{array}$ & 117 & 239 & 480 \\
\hline $\mathrm{pH}$ & 7.65 & 6.91 & 7.11 \\
\hline $\begin{array}{l}\mathrm{biogas} \\
\mathrm{m} / \mathrm{d}\end{array}$ & 81.2 & 152.8 & 299.8 \\
\hline
\end{tabular}

Mass balances of carbon for 10 days HRT are shown in Table 5. The TOC in the influent has four fates: 1) converted into IC in the effluent, 2) converted into biogas, 3) adsorbed by the microbial cells, and 4) left as the residure TOC in the effluent. The amount of 
carbon used in the biosynthesis of microbial cells may be too small to be considered in the mass balance.

When the amount in the fates 1,2 , and 4 were measured, the amount of carbon adsorbed by the microbial cells could be estimated from the overall carbon mass balance. The results, as shown in Table 5, indicate that $40 \%$ of the influent TOC is converted into IC, $25 \%$ into biogas, $25 \%$ is adsorbed, and $10 \%$ is left as TOC in the effluent. The amount of carbon absorbed by the microbial cells is either converted eventually or desorbed back to the solution. The desorption was observed when the TOC in the influent was reduced from 265.7 to 183.4 and then to 170.8. Under this condition, the mass balance indicates a negative adsorption as shown in Table 5.

Table 5. Mass balance of carbon* for 10 days HRT.

\begin{tabular}{|c|c|c|c|c|c|c|}
\hline day & 1 & 2 & 3 & 4 & 5 & 6 \\
\hline TC $\mathrm{i}$ & 265.6 & 265.6 & 267.9 & 185.9 & 173.4 & 192 \\
\hline $\begin{array}{l}\text { TOC } \\
\mathrm{i}\end{array}$ & 263.4 & 263.4 & 265.7 & 183.4 & 170.8 & 189 \\
\hline IC $\mathrm{i}$ & 2.2 & 2.2 & 2.1 & 2.5 & 2.6 & 2.8 \\
\hline TCe & 127.2 & 134.2 & 130.3 & 123.1 & 135.6 & 102 \\
\hline $\begin{array}{l}\text { TOC } \\
\text { e }\end{array}$ & 23.9 & 35.9 & 17.1 & 18.3 & 21.8 & 22.8 \\
\hline ICe & 103.2 & 98.4 & 113.6 & 104.8 & 113.9 & 65.1 \\
\hline $\begin{array}{l}\text { bio- } \\
\text { gas }\end{array}$ & 66.5 & 74.1 & 87.4 & 72.2 & 61.7 & 71.2 \\
\hline $\begin{array}{l}\text { adso } \\
\text { rbed }\end{array}$ & 71.9 & 57.3 & 50.2 & -9.4 & -33.5 & 28.2 \\
\hline
\end{tabular}

The unit of the carbon here is $\mathrm{mg}$.

$$
\mathrm{i}=\text { influent }
$$

$e=$ effluent

The mass balances of nitrogen, phosphorus, and potassium are shown in Table 6. It can be seen from the influent and effluent of this table that the $95 \%$ of nitrogen and phosphorus and $92 \%$ of potassium are left in the effluent solution. This high N-P-K content solution may serve as a good nutrient for the plant growth.
Table 6. Mass balance of N-P-K for 10 days HRT.

\begin{tabular}{|l|c|c|c|}
\hline element & $\mathrm{N}$ & $\mathrm{P}$ & $\mathrm{K}$ \\
\hline inf, $\mathrm{mg} / \ell$ & 496.5 & 47.4 & 142.0 \\
\hline eff, $\mathrm{mg} / \ell$ & 470.0 & 44.5 & 130.0 \\
\hline consumed & 26.5 & 2.9 & 12.0 \\
\hline
\end{tabular}

\section{Epidemiology}

The declines of viable counts of Salmonella choleraesuis during continuous (withdrawn-and-fed) mesophilic anaerobic digestion at different HRT are illustrated in Figure 4. This figure indicates that the viable counts of Samonella choleraesuis at the three HRT declined rapidly within the first 4 days after inoculation.

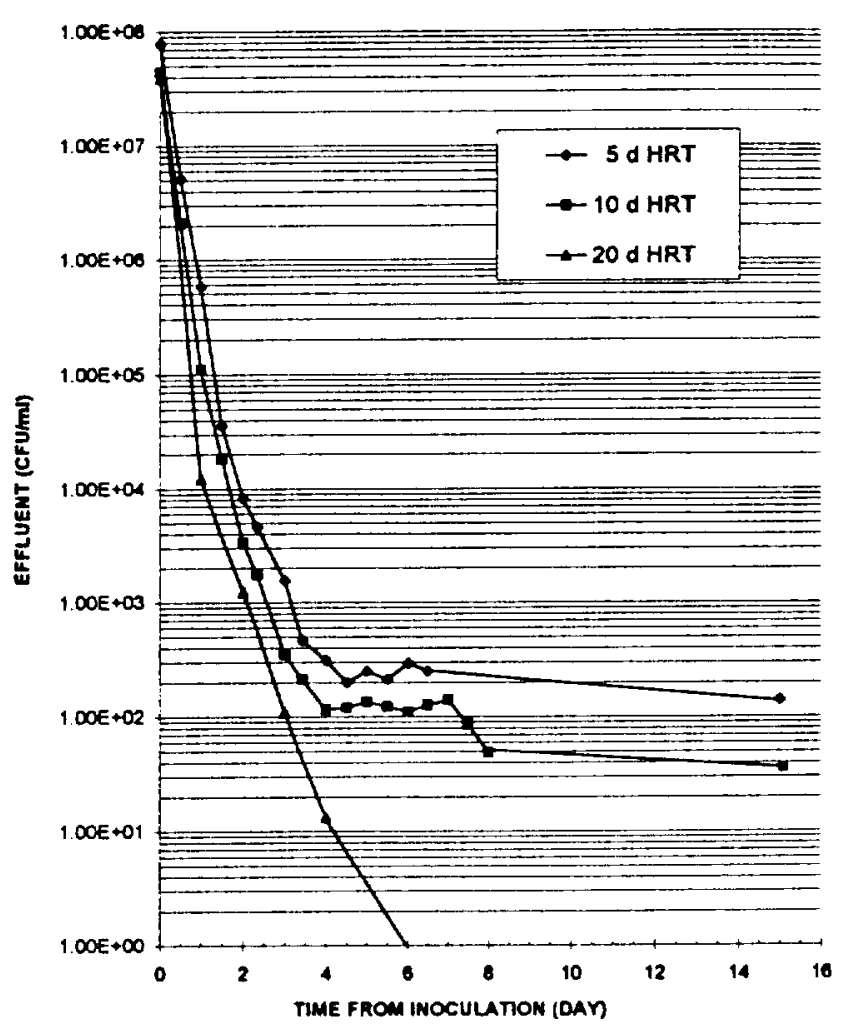

Fig. 4. Survival of Salmonella Choleraesuis in the single dose continuous anaerobic digestion $(\mathrm{pH}=7.12)$. 
The rapid declines of viable count of Salmonella choleraesuis were followed by a period of equilibrium for both 5 and $10 \mathrm{~d} \mathrm{HRT}$. However, for the $20 \mathrm{~d}$ HRT the viable count drops continuously to a level below the detectable limit. This phenomena could be explained by a lack of nutrient at the $20 \mathrm{~d}$ HRT operation.

The decimal decay rate $\left(k_{d}\right)$ for the continuous digestion studies was calculated using the modified formula by Ginnivan. ${ }^{3}$

$$
k_{d}=-\frac{1}{t} \ln \left(\frac{P}{P_{0}}\right)-\frac{V}{V}
$$

where, $\mathrm{P}$ is the colony count of indicator bacteria in the withdrawn effluent, $P_{O}$ is the initial viable count in the digester (CFU/ml), $v$ is the liquid volume of the effluent removed per day ( $\mathrm{ml} /$ day), $\mathrm{V}$ is the liquid volume in the digester (ml), and $t$ is the time interval (day). For a batch digestion system, the flow rate, $\mathrm{v}$, is set to zero. The decimal decay rate $\left(k_{d}\right)$ for the single-dose continuous digestion and batch digestion studies were determined from the slope of a plot of $\left(\mathrm{P} / \mathrm{P}_{0}\right)$ versus $t$ on a semi-logrithemic scale as shown in Figure 5 for $5 \mathrm{~d}$ HRT. Linear regression methods were used to estimate the slope and only those data within 4 days were used.

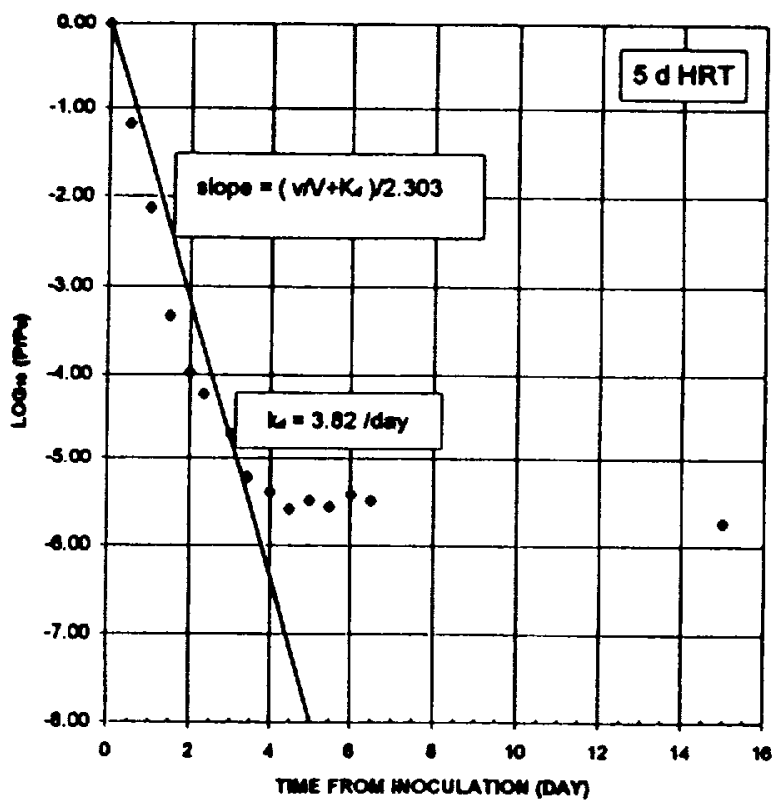

Fig. 5. Determination of $k_{d}$ of Salmonella choleraesuis in the sigle dose continuous anaerobic digester for $5 \mathrm{~d}$ HRT.
Differences among the $k_{t}$ at various HRT dur.ng continuous digestion were assessed by calculating tipper and lower $95 \%$ confidence intervals. The $k_{d}$ values were significantly different if their $95 \%$ confidence intervals did not overlap. The investigation of the effect of the various HRT on the survival time of Samonella cholenaesuis showed greater variations. Using an iritial dose of approximately $10^{7} \mathrm{CFU} / \mathrm{ml}$ for each HRT study, at an HRT of 20 days, the indicator bacteria were found to be below the level of detection by the end of the 6th day of the study. However, after a period of rapid decline in viable numbers, at HRT of 10 and 5 day:; the indicator bacteria reached equilibrium (the viable numbers were not reduced by one logarithmic unit) by the end of the 15th day at approximately $40 \mathrm{CFU} / \mathrm{ml}$ for $10 \mathrm{~d} \mathrm{HRT}$ and $1.4 \times 10^{2} \mathrm{CFU} / \mathrm{ml}$ for $5 \mathrm{~d} \mathrm{HRT}$.

The decimal decay rates $\left(\mathrm{k}_{\mathrm{q}}\right)$ of the Salmonella cholenaesuis during single-dose continuous mesophilic digestion operated at 20,10 and $5 \mathrm{~d}$ HRT are calcu ated and listed in Table 7 with upper and lower $95 \%$ confidence intervals. ${ }^{6}$ The three $k_{d}$ values were not significantly different because their $95 \%$ confidence intervals overlapped. The $\mathrm{pH}$ and biogas production during single-dose continuous digestion remained relatively stable throughout the digestion with a mertn $\mathrm{pH}$ of 7.12 and mean biogas production of 183 $\mathrm{mV}$ interval which contained a mean of $71 \%$ methane.

Table 7. Decimal decay rate constant, $k_{d}$, of Salmonella Choleraesuis during single dose continuous anaerobic digestion.

\begin{tabular}{|l|l|l|l|}
\hline HRT, day & $k_{\downarrow}$ dya $^{-1}$ & $\begin{array}{l}\text { lower limit } \\
k_{d} \text { day' }\end{array}$ & $\begin{array}{l}\text { upper limit } \\
k_{d} \text { day }^{-1}\end{array}$ \\
\hline 20 & 4.28 & 3.07 & 5.48 \\
\hline 10 & 3.82 & 2.88 & 4.76 \\
\hline 5 & 3.82 & 3.36 & 4.28 \\
\hline
\end{tabular}

The effect of bacterial feeding dose on the decimal decay rate $\left(k_{1}\right)$ of Salmonella cholenaeszis i:; shown in Figure 6. The correlation values $(r)(0.62$ at 20 d HRT; 0.87 at $10 \mathrm{~d}$ HRT; 0.90 at $5 \mathrm{~d}$ HRT) indicate that there is a strong positive relationship between the bacterial viable count of the initial dose and their $k_{d}$ values. Biogas production and $\mathrm{pH}$ remained relatively stable throughout this digestion also with a mean $\mathrm{pH}$ of 
7.48 and mean biogas production of $123 \mathrm{ml} /$ interval which contained a mean of $71 \%$ methane.

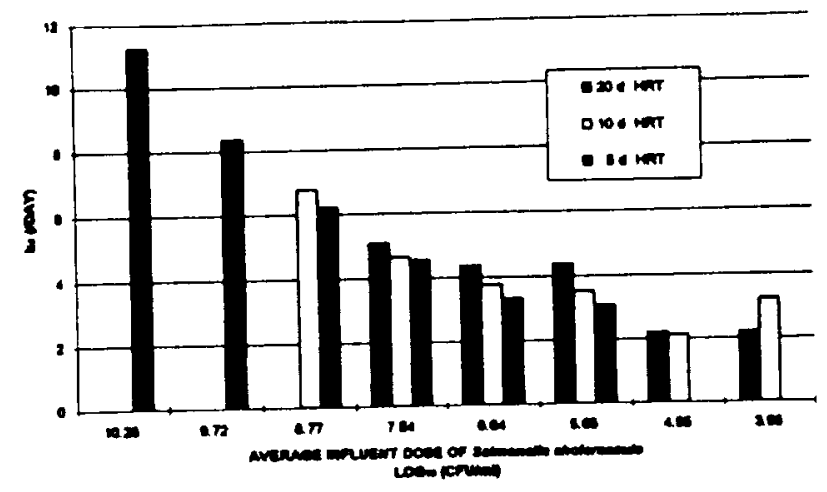

Fig. 6. Influent dose of Salmonella Choleraesuis and their $k_{d}$ in the multi-dose study during continuous mesophilic anaerobic digestion under various HRT.

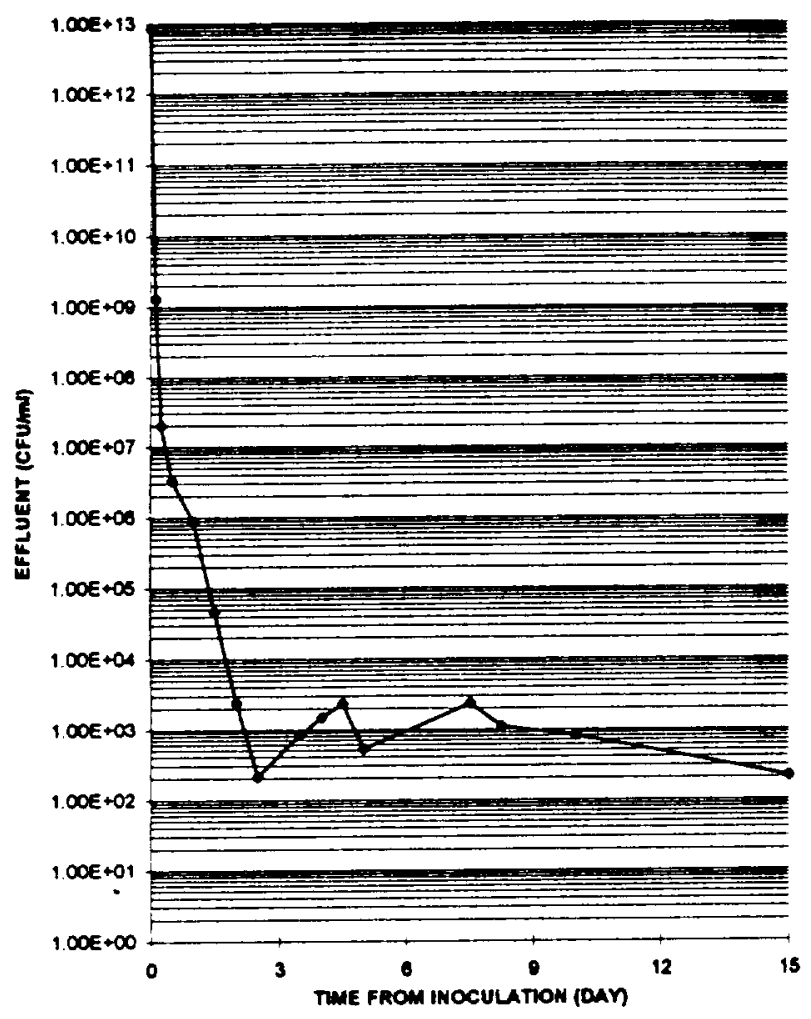

Fig. 7. The inactivation of Salmonella choleraesuis during batch mesophilic anaerobic digestion.
A rapid decline in the viable count of Salmonella choleraesuis during batch mesophilic anaerobic digestion is shown in Figure 7.The viable count of Salmonella choleraesuis declined rapidly within the first 2-4 days after inoculation. This rapid docline was followed by a period of equilibrium where the indicator bacteria remained at $10^{2} \mathrm{CFU} / \mathrm{ml}$ until the 15 th day from the inoculation. The decimal decay rate $\left(k_{d}\right)$ of the Salmonella cholenaesuis during batch mesophilic digestion is calculated by the same method used in the single-dose continuous process. The value of $k_{d}$ calculated is 7.89 day'.

The viable counts of effluent correlated with the biogas suggesting a strong negative relationship $(r=-0.85)$. A rapid decline in the viable population of the indicator bacteria was reflected in a large volume of biogas production; as biogas production declined, so did the viable population of the indicator bacteria in the digester. The $\mathrm{pH}$ values remained relatively stable throughout batch mesophilic digestion with a mean value of 6.90. The viable counts and the $\mathrm{pH}$ value did not show a relationship $(r=-0.07)$.

\section{Conclusion}

Results indicate that the NASA simulated wastewater can be treated by anaerobic digestion. Mass balances indicate about $90 \%$ of the TOC is converted while only 5 to $8 \%$ of N-P-K are consumed in the digester. The maximum organic loading capacity was not reached indicating there is a possibility of increasing the loading rate. Salmonella choleraesuis survived at least 15 days from inoculation for 10 and 5 days HRT during continuous and batch digestion, but less than 6 days for 20 days HRT. The $k_{y}$ values were greater at higher initial doses than lower doses for the same HRT, and greater for batch digestion (7.89 day ${ }^{1}$ ) than for continuous digestion $\left(4.28,3.82\right.$ and 3.82 day $^{1}$ for 20 , 10 and $5 \mathrm{~d}$ HRT, respectively).

\section{Acknowledgement}

The financial support from NASA-JSC through a grant NGA 9-696 and a partial student support from the reserach grant at Lamar University are appreciated.

\section{Reference}

1. Flyn, M T. (1992). Water reclamation technology development for future long range missions (SAE 
Technical Paper Series 921351). 22nd

International Conference on Environmental

Systems. Seattle, Washington.

2. Greenberg, A. E. (Ed.). (1992). Standard methods for the examination of water and wastewater (18th ed.). Washington, D.C.: American Public Health Association.

3. Ginnivan, M J. (1980). Survival of Salmonella dublin in pig slurry during aerobic thermophilic treatment in batch, cyclic and continuous systems. Joumal of Applied Bacteriology, 40, 13-18.

4. Henninger, D. (1993). Controlled ecological life support systems (CELSS) research and technology development at the Johnson Space Center. (CELSS Conference of 1993) Alexandria, Virginia.

5. Li, K.Y. and M.D. Hunt (1994). Resource recovery and epidemiolopy of anaerobic wastewater treatment process in a controlled ecolopical life support system, project report to NASA-JSC.

6. Mosteller, F., Fienberg, S. E., \& Rourke, R. E. K (1983). Beginning statistics with data analysis (pp. 327). California: Addison-wesley publishing company.

7. Pertrie, G. E. (1991). Development of immobilized cell bioreactor technology for water reclamation in a regenerative life support system (SAE Technical Paper Series 911503). 22nd International Conference on Environmental Systems. Seattle, Washington.

8. Schwartzkopf, S. H. (1992a). Design of a controlled ecological life support system. BioScience, 42, 526-535.

9. Wolverton, B. C., MacDonald, R. C., \& Duffer, W. R. (1983). Microorganisms and higher plants for waste water treatment. Jourmal of Environmental Ouality, 12, 236-242. 